\title{
IBM BANTUAN PERAHU MOTOR UNTUK KELOMPOK NELAYAN SEJAHTERA DI DESA JARING HALUS KECAMATAN SICANGGANG UNTUK MENINGKATKAN PENGHASILAN DAN TARAF HIDUP NELAYAN
}

\author{
Farida Ariani $^{1}$, Ikhsan Siregar ${ }^{1}$ \\ ${ }^{1}$ Departemen Teknik Mesin Fakultas Teknik Universitas Sumatera Utara Jl. Almamater Kampus USU Medan - \\ 20155, Telp/Fax. 061-8213250 e-mail :
}

\begin{abstract}
Abstrak
Nelayan adalah suatu kelompok masyarakat yang kehidupannya tergantung langsung pada hasil laut, baik dengan cara melakukan penangkapan ataupun budidaya. Mereka pada umumnya tinggal di pinggir pantai, sebuah lingkungan pemukiman yang dekat dengan lokasi kegiatan. Kehidupan nelayan sampai saat ini belum dapat dikatakan layak bahkan jauh dari kata sejahtera. Banyak faktor yang menyebabkan keadaan ekonomi nelayan Indonesia masih jauh dari sejahtera, seperti cara penangkapan yang masih tergolong tradisional, pendidikan yang rendah dan sistem rantai penjualan hasil tangkapan ikan yang terlalu panjang. Oleh sebab itu perlunya bantuan yang cukup signifikan kepada para masyarakat nelayan di Indonesia pada umumnya. Karena mereka tidak akan bisa berkembang tanpa adanya bantuan dari pihak lain untuk merubah nasibnya. Saat ini juga ada suatu keadaan dimana banyak masyarakat nelayan yang tidak memiliki perahu karena disebabkan oleh satu dan lain hal. Mereka hanya mengandalkan pencarian dari bekerja di perahu nelayan lainnya, mereka harus berbagi penghasilan dari sebuah perahu yang sedikit itu, sehingga taraf kehidupan mereka sangat rendah sekali. Hal inilah yang menjadi perhatian tim pengabdian masyarakat USU, untuk dicarikan solusinya, bagaimana cara menaikkan taraf hidup salah seorang mitra nelayan di desa Jaring Halus. Pada proposal program pengabdian masyarakat ini direncanakan untuk memberikan bantuan kepada mitra nelayan, dengan memberi bantuan perahu dan bimbingan agar terjadi peningkatkan penghasilan, yang diharapkan dapat menaikkan taraf hidupnya.

Metode pelaksanaan yang dipakai dalam menyelesaikan masalah ini adalah metode deskriptif kualitatif dengan menggunakan data primer dan sekunder.
\end{abstract}

Kata kunci : bantuan peralatan, nelayan, taraf hidup rendah

\section{PENDAHULUAN}

Nelayan adalah suatu kelompok masyarakat yang kehidupannya tergantung langsung pada hasil laut, baik dengan cara melakukan penangkapan ataupun budidaya. Mereka pada umumnya tinggal di pinggir pantai, sebuah lingkungan pemukiman yang dekat dengan lokasi kegiatan. Kehidupan nelayan sampai saat ini belum dapat dikatakan layak bahkan jauh dari kata sejahtera.

Banyak faktor yang menyebabkan keadaan ekonomi nelayan Indonesia masih jauh dari sejahtera, seperti cara penangkapan yang masih tergolong tradisional, pendidikan yang rendah dan sistem rantai penjualan hasil tangkapan ikan yang terlalu panjang.
Sejauh ini kebanyakan nelayan Indonesia masih digolongkan pada golongan tradisional. Pada tahun 2015, dari 590.352 kapal ikan Indonesia, hanya 6.370

unit kapal (kurang dari 2\%) yang tergolong modern (kapal motor berukuran di atas 30 GT). Sedangakan kapal motor yang beroperasi sebanyak 155.992 unit (26\%). Selebihnya, 238.430 unit (40\%) berupa perahu motor tempel (outboard motor) dan 189.630 unit (32\%) berupa perahu tanpa motor yang hanya menggunakan layar dan dayung (KKP, 2015). Berdasarkan data tersebut menunjukkan bahwa nelayan Indonesia mayoritas adalah nelayan tradisional dimana hanya mengandalkan perahu motor tempel dalam melaut. 
Farida Ariani et al. IbM Bantuan Perahu Motor Untuk Kelompok Nelayan Sejahtera ...

Oleh sebab itu perlunya bantuan yang cukup signifikan kepada para masyarakat nelayan di Indonesia pada umumnya. Karena mereka tidak akan bisa berkembang tanpa adanya bantuan dari pihak lain untuk merubah nasibnya. Saat ini juga ada suatu keadaan dimana banyak masyarakat nelayan yang tidak memiliki perahu. Mereka hanya mengandalkan pencarian dari bekerja di perahu nelayan lainnya sehingga mereka harus berbagi penghasilan yang sedikit itu. Hal inilah yang harusnya menjadi perhatian untuk dicarikan solusi agar setiap nelayan dapat memiliki perahu sendiri agar dapat meningkatkan penghasilannya.

\subsection{Permasalahan Mitra}

Bagi seorang nelayan, perahu merupakan alat utama untuk melaut mencari ikan. Akan tetapi saat ini perahu bukanlah barang yang harganya murah, sehingga melihat keadaan ekonomi umumnya para nelayan pada saat ini, yang memprihatinkan, tidak semua nelayan bisa memiliki perahu. Jadi hal ini merupakan suatu dilema, seorang nelayan tidak memiliki perahu.

Kondisi tersebut diatas itulah yang banyak terjadi di desa Jaring Halus Kecamatan Sicanggang Kabupaten Langkat saat ini, salah satunya terjadi pada mitra pengabdian. Pada akhirnya mitra terpaksa menganggur atau terkadang bekerja pada perahu nelayan lainnya. Kondisi ini berdampak buruk pada kehidupan mitra dan keluarganya, karena penghasilan mitra sudah kecil dan ditambah lagi tidak pasti, kadang ada kadang tidak. Jika keadaan tersebut dibiarkan terus tentu akan berdampak buruk bagi mitra dan keluarganya. Dan mungkin saja dapat berujung kepada terjadinya masalah-masalah sosial yang lebih kompleks lagi. Untuk itulah tim Pengabdian Masyarak USU mencoba memberikan bantuan pemberian satu unit perahu motor untuk mengatasi masalah mitra yang merupakan salah seorang nelayan di desa Jaring Halus.

\section{METODE PELAKSANAAN}

\subsection{Tempat dan Waktu}

Tempat kegiatan pengabdian pada masyarakat ini dilakukan di Desa Jaring Halus Kec. Sicanggang Kab. Langkat Sumatera Utara. Lama waktu kegiatan mulai dari perencanaan hingga pelaksanaan di lokasi target sekitar 6 (enam) bulan .

\subsection{Pelaksanaan Kegiatan}

Untuk mewujudkan kegiatan tersebut maka dibuat suatu teknik pelaksanaan agar kegiatan yang akan dilaksanakan dapat berjalan sesuai dengan jadwal, terstruktur dan tepat sasaran. Berdasarkan hal-hal di atas maka dibuatlah suatu solusi untuk mengatasi masalah yang dihadapi mitra dengan beberapa tahapan yakni studi kepustakaan, pelaksanaan survei mencari akar permasalahan permasalahan nelayan di lapangan hingga pembuatan kapal kayu bermotor sebagai solusi yang ditawarkan kepada mitra di lokasi target. Tahap pelaksanaan kegiatan dapat diuraikan sebagai berikut :

1. Melakukan survei literatur dan survei lapangan

2. Merencanakan pembuatan kapal kayu bermotor.

3. Mengadakan penyuluhan mengenai perawatan kapal kayu bermotor.

4. Melakukan serah terima kapal kayu bermotor kepada mitra

5. Melakukan penulisan laporan akhir dan publikasi

\subsection{Bahan dan Peralatan}

Perancangan dan pembuatan perahu motor nelayan dilakukan setelah diperoleh data-data dari hasil survey lapangan, seperti dimensi perahu, jenis perahu dan lain-lain. Peralatan dan bahan yang diperlukan seperti motor diesel $27 \mathrm{Hp}$, peralatan kemudi perahu, gear box, balingbaling perahu dan bahan yang paling utama 
adalah kayu, seperti dapat dilihat pada

Gambar 2.1.
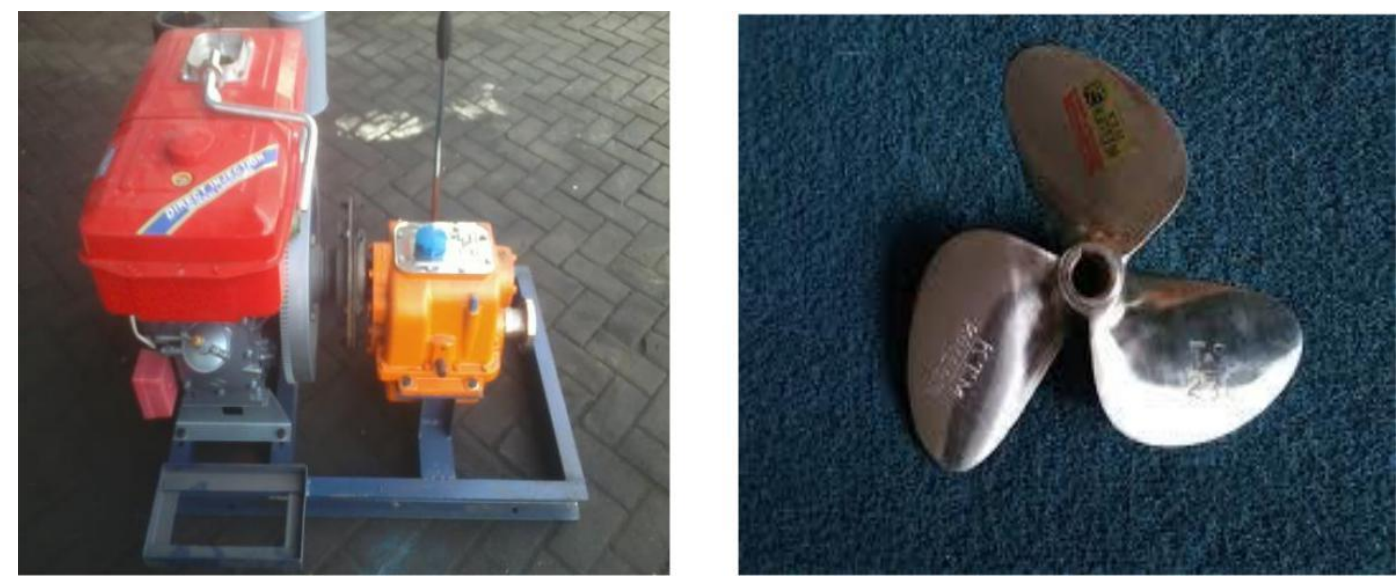

Gambar 2.1. Beberapa peralatan perahu motor yang digunakan

\section{Hasil dan Pembahasan Kegiatan}

\subsection{Pembuatan Perahu Motor Nelayan}

Proses pembuatan perahu motor untuk nelayan ini memakan waktu lebih kurang 2 bulan. Setelah selesai pembuatan badan perahu lalu dilakukan pemasangan mesin diesel sebagai penggerak perahu beserta baling-balingnya dan kemudian dipasang sistim kemudinya, barulah setelah itu dilakukan uji coba menjalankan perahu motor tersebut ke laut. Foto Dokumentasi kegiatan pengabdian ini dapat dilihat pada Gambar 3.1. 
Farida Ariani et al. IbM Bantuan Perahu Motor Untuk Kelompok Nelayan Sejahtera ...
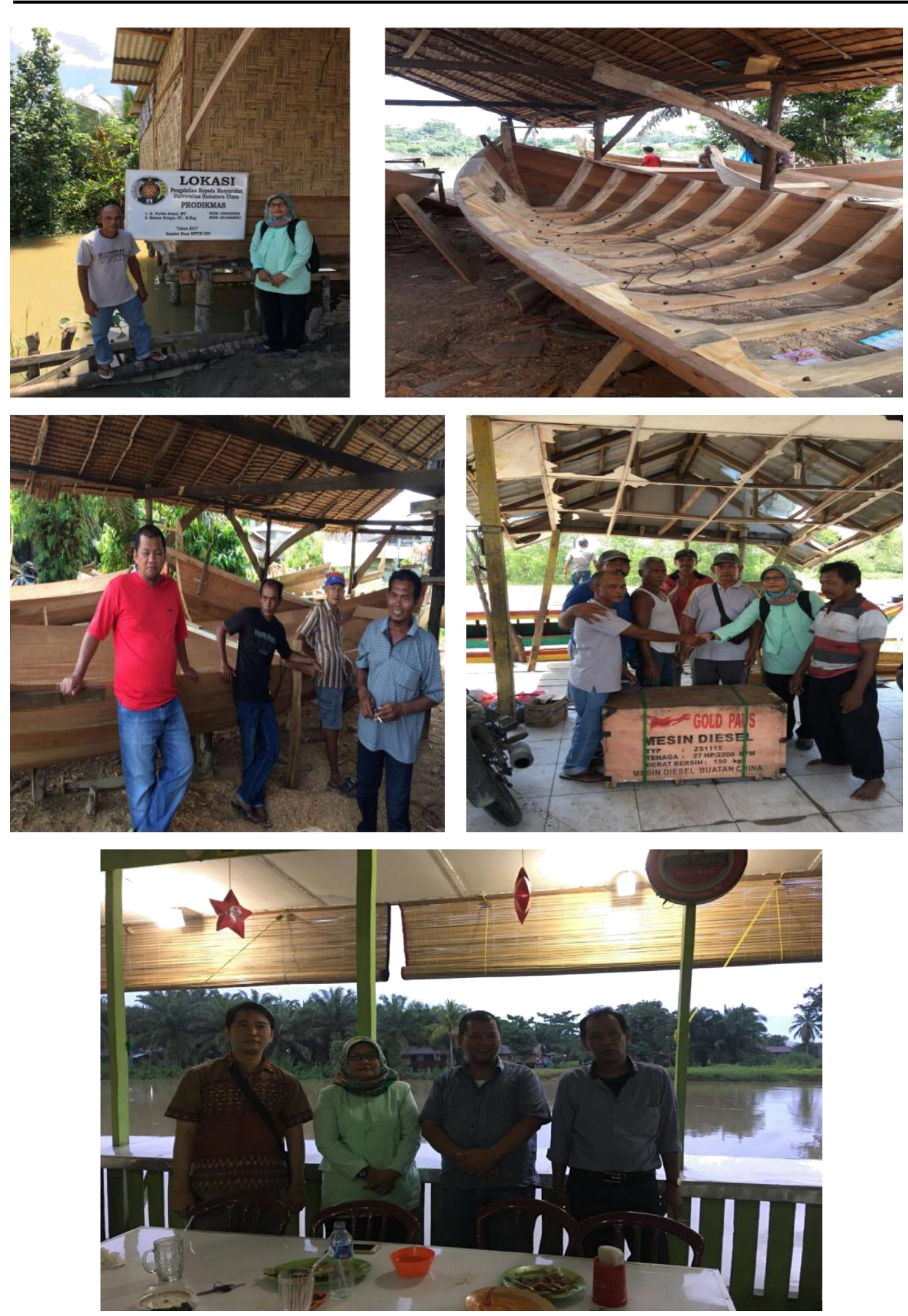

Gambar 3.1. Foto dokumentasi kegiatan pengabdian masyarakat di desa Jaring Halus 


\section{Luaran yang Dicapai}

Luaran yang dicapai dari kegiatan pengabdian pada masyarakat ini adalah pemberian bantuan 1 (satu) unit perahu nelayan bermotor 27 HP beserta perlengkapannya yang bertujuan untuk meningkatkan produktifitas mitra nelayan guna menaikkan pendapatan dan taraf hidupnya. Dan dari hasil pengamatan selama kurang lebih satu bulan setelah penyerahan perahu motor tersebut, mitra nelayan sudah mulai dapat merasakan sedikit perubahan positif dalam kehidupannya.

\section{KESIMPULAN}

Dari kegiatan yang dilakukan selama lima bulan ini dapat disimpulkan sebagai berikut :

1. Telah dibuat dan diserahkan bantuan kepada mitra nelayan berupa 1 (satu) unit perahu bermotor ukuran $27 \mathrm{ft}$ beserta peralatannya untuk nelayan mitra di desa Jaring Halus Kecamatan Secanggang Kabupaten Langkat Sumatera Utara.

2. Peralatan ini sangat berguna bagi mitra nelayan karena yang selama ini mitra sangat bergantung kepada nelayan lain untuk dapat melaut, tetapi dengan adanya pemberian bantuan perahu ini, mitra nelayan sudah dapat mandiri.

3. Kontribusi mendasar pada khayalak sasaran yaitu memberikan manfaat pada mitra nelayan dalam hal meningkatnya produktifitas sehingga menaikkan taraf hidupnya

\section{Ucapan Terimakasih}

Tim $\begin{gathered}\text { pelaksana } \\ \text { kepada }\end{gathered} \begin{array}{r}\text { kegiatan } \\ \text { masyarakat }\end{array}$
mengabdian
Universitas Sumatera Utara melalui
Lembaga Pengabdian Pada Masyarakat
(LPPM) atas penyediaan seluruh dana
kegiatan pengabdian pada masyarakat
tahun 2017 sehingga kegiatas diatas dapat
terlaksana.

\section{Daftar Pustaka}

[1] Thomas W. Zimmerer, Norman M. Scarborough, 2008,

Kewirausahaan dan Manajemen Usaha Kecil Edisi 5, Salemba Empat.

[2] Direktorat Riset dan Pengabdian kepada Masyarakat, Dirjen Penguatan Riset dan Pengembangan, Kemenristek Dikti, Panduan Pelaksanaan Penelitian dan Pengabdian Kepada Masyarakat di Perguruan Tinggi, Edisi X, 2016

[3] Hardi Prasetyo 2013, Gambar konstruksi perahu nelayan tradisional Indonesia,.

[4] Suwardi Handoko, 2012, Desain Konstruksi Perahu, Gramedia. 